\title{
Low burrow occupancy and breeding success of burrowing petrels at Gough Island: a consequence of mouse predation
}

\author{
RICHARD J. CUTHBERT, HENK LOUW, JEROEN LURLING, \\ GRAHAM PARKER, KALINKA REXER-HUBER, ERICA SOMMER, \\ PAUL VISSER and PETER G. RYAN
}

\section{Summary}

The predatory behaviour of introduced house mice Mus musculus at Gough Island is known to impact on albatross and petrels, resulting in the Tristan Albatross Diomedea dabbenena and Atlantic Petrel Pterodroma incerta being listed as "Critically Endangered" and "Endangered", respectively. Although predation has been documented for two burrowing petrels and one albatross species, the impact of house mice on other burrowing petrels on Gough Island is unknown. We report burrow occupancy and breeding success of Atlantic Petrels, Soft-plumaged Petrels Pterodroma mollis, Broadbilled Prions Pachyptila vittata, Grey Petrels Procellaria cinerea and Great Shearwaters Puffinus gravis. With the exception of the Great Shearwater, breeding parameters of burrowing petrels at Gough Island were very poor, with low burrow occupancy (range 4-42\%) and low breeding success $(\mathrm{o}-44 \%)$ for four species, and high rates of chick mortality in Atlantic Petrel burrows. Breeding success decreased with mass, suggesting that smaller species are hardest hit, and winter-breeding species had lower breeding success than summer breeders. The results indicate that introduced house mice are having a detrimental impact on a wider range of species than previously recorded and are likely to be causing population declines among most burrowing petrels on Gough Island. The very low values of burrow occupancy recorded for Soft-plumaged Petrels and Broad-billed Prions and greatly reduced abundance of burrowing petrels in comparison to earlier decades indicate that Gough Island's formerly abundant petrel populations are greatly threatened by the impact of predatory house mice which can only be halted by the eradication of this species from the island.

\section{Introduction}

Invasive species impact upon one third of the world's threatened bird species and invasive mammalian predators are a major driver in the ongoing deterioration in the status of the world's birds (Butchart 2008, Hilton and Cuthbert 2010). Among the invaders, rodents are nearubiquitous in their ability to colonise islands and the negative impacts of rats Rattus spp. are well known (Moors and Atkinson 1984, Atkinson 1985, Jones et al. 2008). Unlike rats, the impact of the house mouse Mus musculus has until recently been thought to be relatively small, but the discovery that the house mouse is a predator of albatross and petrel chicks at Gough Island has demonstrated that mice can be an important threat to a wide range of seabirds (Cuthbert and Hilton 2004, Wanless et al. 2007, Angel et al. 2009). Gough Island in the South Atlantic Ocean is renowned for being one of the world's most important seabird breeding islands (Swales 1965, Collar and Stuart 1985), supporting at least 20 species of seabird including tens of millions of burrowing petrels and albatrosses (Ryan et al. 2001, Cuthbert 2004, Cuthbert and Sommer 2004a). More recently, Gough Island has become as well known for the predatory behaviour of 
mice that were accidentally introduced to the island by sealers in the early $19^{\text {th }}$ century (Rowe-Rowe and Crafford 1992) and which have been shown to kill burrowing petrel chicks and even chicks of the Tristan Albatross Diomedea dabbenena (Cuthbert and Hilton 2004, Wanless et al. 2007). The impact of this predation is severe and is driving population declines of both Tristan Albatrosses and Atlantic Petrels Pterodroma incerta (Cuthbert 2004, Wanless et al. 2009), resulting in these species being listed as "Critically Endangered" and "Endangered", respectively (BirdLife International 2004). The endemic Gough Bunting Rowettia goughensis is also "Critically Endangered" due to predation and competition with house mice (Ryan and Cuthbert 2008).

To date, direct evidence for mouse predation on Gough's seabird species has been recorded on chicks of the Tristan Albatross, Atlantic Petrel, and Great Shearwater Puffinus gravis (Wanless et al. 2007). Although predation events have been recorded throughout the year, the impact of this predation appears to be most severe for winter-breeding species such as Tristan Albatross and Atlantic Petrel (Cuthbert and Hilton 2004). In contrast, summer-breeding species such as Great Shearwater, Southern Giant Petrel Macronectes giganteus, Atlantic Yellow-nosed Albatross Thalassarche chlororhynchos and Sooty Albatross Phoebetria fusca have high values of chick survival and overall breeding success (Cuthbert 2005, Cuthbert and Hilton 2004, Cuthbert et al. submitted.). Due to these seasonal differences in predation rates, it is likely that other winterbreeding species on Gough Island also are severely impacted by mouse predation (Angel and Cooper 2006). It is also likely that smaller petrels on Gough Island, such as storm petrels and diving petrels, also suffer high predation rates (Angel and Cooper 2006), and anecdotal observations point to large-scale decreases in the numbers of several smaller species (Ryan 2010). In this study we report rates of burrow occupancy and breeding success for a wider range of burrowing petrels on Gough Island. In light of our results we discuss the likely impact of house mice on their populations and on populations of other burrowing petrel species on the island.

\section{Methods}

\section{Study site and species}

Gough Island $\left(40^{\circ} 21^{\prime} \mathrm{S}, 9^{\circ} 53^{\prime} \mathrm{W}\right)$ is part of the UK Overseas Territory of Tristan da Cunha. It is a volcanic island of c. $65 \mathrm{~km}^{2}$ in area with steep mountainous terrain. Four main vegetation types are found on Gough Island (Wace 1961, Cooper and Ryan 1994): coastal tussock (mainly comprising Spartina arundinacea and Parodiochloa flabellata), fernbush (dominated by the deciduous fern Histiopteris incisa, the island tree Phylica arborea and bog-ferns Blechnum palmiforme), upland wet heath (comprising a diverse assemblage of species found in all other vegetation types), feldmark, and peat bogs. There are no native terrestrial mammals and the only introduced vertebrate is the house mouse that arrived with sealers prior to the 1880 os (Rowe-Rowe and Crafford 1992). At least 12 species of burrowing petrels breed on the island and are distributed within all habitats with the exception of peat bogs, areas of bare rock and the highest exposed peaks.

\section{Fieldwork methods}

Teams were based on Gough Island in three seasons (2008/09, 2009/10 and 2010/11), with fieldwork running for 13 months from September to September of each season. Studies of burrow occupancy and breeding success were carried out for five species: Atlantic Petrel, Soft-plumaged Petrel Pterodroma mollis, Broad-billed Prion Pachyptila vittata, Grey Petrel Procellaria cinerea and Great Shearwater. Attempts were also made to monitor breeding success of Great-winged Petrels Pterodroma macroptera, Common Diving Petrels Pelecanoides urinatrix, Grey-backed Storm Petrels Garrodia nereis, White-faced Storm Petrels Pelagodroma marina and White-bellied/Black-bellied Storm Petrels (Fregatta grallaria/tropica). Where applicable, data are also presented from fieldwork undertaken in 2000/01 (Cuthbert 2004, 2005, unpubl. data). 
Breeding petrels were monitored through digging study-hatches in burrows (2000/2001 and 2008/o9) and/or through the use of an infra-red burrow-scope (manufactured by Sextant Technologies, New Zealand) (2009/10 and 2010/1I). The identity of petrel burrows was inferred from the size and shape of the burrow entrance, vegetation type and altitude (Swales 1965, Cuthbert 2004, Cuthbert and Sommer 2004b). For all species, burrows were checked in the prebreeding period and early in the incubation period in order to identify burrows containing prospecting pairs and/or incubating birds. After an incubating bird was detected, the burrow was left undisturbed throughout the incubation period to reduce the risk of desertions. Burrows were checked 7-10 days after the estimated hatching date to quantify hatching success. The timing of breeding was based on dates reported in Ryan (2007) and the known breeding phenology for Great Shearwaters and Atlantic Petrels (Cuthbert 2004, 2005) or from the relationship between petrel egg size and incubation period (from Warham 1990). After hatching, some burrows were checked every 5-14 days until fledging, while others were checked only once, close to the end of the chick-rearing period but prior to the estimated fledging date. Large chicks which had grown contour feathers and lost most of their down were assumed to survive to fledge. A further sample of Broad-billed Prion chicks was observed at a cave site on the island, as large numbers of prions breed in caves on Gough Island (Cuthbert et al. 2011). This cave was visited at monthly intervals from 20 January 2009 when small, newly hatched chicks were present and observations were made on the presence of dead or injured chicks.

For all species, we report values of burrow occupancy (the proportion of burrows occupied by breeding pairs) and calculate maximum breeding success based on the proportion of incubating eggs producing a fledged chick. Mean estimates are presented \pm one standard error. The total sample of burrows monitored included a proportion of burrows where the contents could not be determined, as some burrows were either, too long and twisted, or too complex, to determine the contents with complete confidence. As a consequence, estimates of burrow occupancy were only calculated for burrows where it was certain that they were empty or contained an incubating bird or pair. Due to the similar size of the species it was difficult to separate potential burrows of Softplumaged Petrels from those of Broad-billed Prions, although it is likely that both species use the same burrows. As a consequence we present two estimates of burrow occupancy: (a) the number containing incubating birds divided by the total number of burrows searched and (b) the number containing incubating birds divided by the number of burrows searched corrected for the relative ratio of Broad-billed Prions to Soft-plumaged Petrels (a ratio of 2.17 : 1; Cuthbert 2004). This second estimate provides a more conservative estimate of burrow occupancy. Because house mice are known to predate even newly hatched chicks being brooded by adult birds (Wanless et al. 2007), estimates of hatching success are only reported for Great Shearwaters where the timing of breeding is known and highly synchronous (Cuthbert 2005) and where chicks could be checked in the days immediately after hatching. Due to the timing of breeding of Atlantic Petrels (which lay eggs from mid-June to mid-July, hatch chicks from mid-August to mid-September and fledge during December and January; Cuthbert 2004) and the timing of field visits to the island (from September to September) "burrow occupancy" is reported for small chicks in September and for large, nearly fledged chicks in December, and chick survival is estimated for this 3-month period.

\section{Results}

\section{Atlantic Petrel}

The contents of 206 burrows were determined with a burrow-scope in September 2010, with additional data from 50 and 63 burrows with study hatches during 2000 and 2001, respectively (Table 1). Burrow occupancy with small chicks was consistent for these three seasons, ranging from 23 to $28 \%$ and an overall mean of $26 \pm 1.4 \%$. Chick survival from September to December was variable (Table 1 ), with survival averaging $49 \pm 10 \%$ for this 3 -month period in the three monitored seasons. Totals of 9, 10 and 6 dead chicks were found within burrows in the 2000, 2001 
Table 1. Breeding data for Atlantic Petrels on Gough Island indicating season, number of burrows with known contents, numbers of small chicks in September, number of large chicks in December and corresponding values of burrow occupancy (\%) and chick survival (\%) for September-December.

\begin{tabular}{llllll}
\hline Season & Burrows & Sep chicks & Dec chicks & Chick occupancy & Survival \\
\hline 2000 & 50 & 14 & 5 & $28 \%$ & $36 \%$ \\
2001 & 63 & 17 & 7 & $27 \%$ & $41 \%$ \\
2010 & 206 & 48 & 33 & $23 \%$ & $69 \%$ \\
\hline
\end{tabular}

and 2010 seasons, respectively, giving minimum chick mortality estimates in these three seasons (from September to December) of $64 \%, 59 \%$ and $13 \%$, respectively and mean chick mortality of $45 \pm 15 \%$. Regular inspection (every 7-10 days) of these Atlantic Petrel burrows indicated that chicks were alive and in apparently good condition and health prior to being found dead in the burrow: suggesting a rapid cause of mortality likely to have been mouse predation.

\section{Soft-plumaged Petrel}

A total of 333 Soft-plumaged Petrel sized burrows were checked with a burrow-scope during November and December 2009, with occupancy determined for 281 burrows (84.4\%). Burrow occupancy for this period was estimated to be $11-18 \%$ (Table 2). Egg-laying for this species occurred from 23 November to 2 December. Of 22 burrows with incubating birds, only 3 produced fledged chicks, giving a crude breeding success of $14 \%$. Limited data from 2000/2001 indicated a breeding success of $44 \%$ (RJC unpubl. data); the pooled estimate of breeding success for both years is $26 \pm 15 \%$.

\section{Broad-billed Prion}

A total of 579 burrows were checked with a burrow-scope in 2009/2010 and 2010/2011, with the occupancy status determined for 461 burrows (79.6\%; Table 2). Burrow occupancy was very low in both seasons with just 4-12\% of burrows estimated to contain incubating birds. While the sample sizes of incubating birds are very small, values of breeding success were poor in both monitored seasons (Table 2), with an overall pooled estimate of breeding success of $6 \pm 5 \%$. Data from the cave site indicated large numbers of birds breeding at this site, with 60 chicks found on 20 January 2009. Further checks of this site revealed the presence of eggshells and dead chicks that had incisor marks on eggs and chick carcasses consistent with house mouse predation. These records include a large, nearly fledged chick which was found with feeding signs indicating it had been partly consumed by mice.

Table 2. Breeding data for Soft-plumaged Petrels, Broad-billed Prions and Grey Petrels on Gough Island indicating season, number of burrows with known contents (values in parentheses are total numbers of burrows checked), numbers of eggs monitored and chicks fledged, and corresponding values of burrow occupancy (\%) and breeding success (\%).

\begin{tabular}{lllllllr}
\hline Species & Season & Burrows & Occupied & Eggs & Fledge & Occupancy & Breed \\
\hline Soft-plumaged Petrel & $2000-01$ & - & - & 16 & 7 & - & $44 \%$ \\
& $2009-10$ & $281(333)$ & 32 & 22 & 3 & $11-18 \%$ & $14 \%$ \\
Broad-billed Prion & $2009-10$ & $256(360)$ & 11 & 11 & 1 & $4-13 \%$ & $9 \%$ \\
\multirow{2}{*}{ Grey Petrel } & $2010-11$ & $205(219)$ & 8 & 7 & 0 & $4-11 \%$ & $0 \%$ \\
& 2009 & - & - & 26 & 8 & - & $31 \%$ \\
& 2010 & $50(141)$ & 21 & 17 & 6 & $42 \%$ & $35 \%$ \\
\hline
\end{tabular}




\section{Grey Petrel}

A total of 141 burrows were checked during 2010, with the contents of 50 burrows determined with certainty with a burrow-scope $(35.5 \%)$. The remaining 91 burrows were too long, wet or twisted for the burrow-scope. Burrow occupancy was $42 \%$ (Table 2). Estimates of breeding success from the 2009 and 2010 seasons were similar (Table 2) with an overall pooled average of $33 \pm 2 \%$.

\section{Great Shearwater}

Burrow occupancy and breeding success of Great Shearwaters were monitored in four years, with 67-180 burrows monitored each year (Table 3). Burrow occupancy was consistently high in all four seasons: $68.7 \pm 2.7 \%$ (range $65-77 \%$ ). Values of hatching success, fledging success and overall breeding success averaged $56.9 \pm 8.5 \%, 81.7 \pm 22.1 \%$ and $43.2 \pm 9.4 \%$, respectively. Fledging success was high in two seasons (93-96\%) and lower (56\%) in one season (Table 3 ).

\section{Discussion}

Globally, seabirds are among the most threatened groups of birds with 97 of 346 species (28\%) listed as globally threatened, including 17 species classified as "Critically Endangered" (Croxall et al. 2012). On their breeding grounds, the gravest threat to seabirds is the impact of introduced mammalian predators (Baker et al. 2002, Croxall et al. 2012), with invasive rodents being among the most serious invasive species (Jones et al. 2008). Our results from Gough Island present a worrying situation for almost all of the burrowing petrels studied here, with low values of burrow occupancy and breeding success recorded for Atlantic Petrel, Broad-billed Prion, Softplumaged Petrel and Grey Petrel. The ranges of breeding success recorded for Atlantic Petrel (2O23\%; Cuthbert 2004, Wanless et al. 2012), Soft-plumaged Petrels (14-44\%), Broad-billed Prions $(0-9 \%)$ and Grey Petrels (31-35\%) from Gough Island are well below the breeding success of most petrels in areas free from introduced predators (Table 4). Only Great Shearwaters had levels of burrow occupancy and breeding parameters that can be considered normal for Puffinus species (Cuthbert and Davis 2002; Table 4).

We consider the predatory behaviour of house mice at Gough Island to be the most logical explanation for these low values of reproductive success. Mouse predation of chicks has been confirmed by direct observation for Atlantic Petrels, Great Shearwaters and Tristan Albatrosses on Gough Island (Wanless et al. 2007) and patterns of injuries indicate predation also occurs on nestlings of Gough Buntings (Ryan and Cuthbert 2008). Further records now suggest that mice also predate Atlantic Yellow-nosed and Sooty Albatross chicks (RSPB unpubl. data). Further direct evidence for predation was recorded for Broad-billed Prions in the current study, where both eggs and chicks of birds breeding in caves (where mice are abundant; Cuthbert et al. 2011)

Table 3. Breeding data for Great Shearwaters on Gough Island indicating season, number of burrows with known contents, numbers of eggs monitored, number of hatched chicks and number of chicks fledged, and corresponding values of burrow occupancy (\%), hatching success (\%), fledging success (\%) and breeding success $(\%)$.

\begin{tabular}{lclllllll}
\hline Season & Burrows & Eggs & Hatch & Fledge & Occupancy & Hatching & Fledging & Breeding \\
\hline $2000-01$ & 67 & 44 & $24(30)^{1}$ & $(28)^{1}$ & $65.7 \%$ & $55.6 \%$ & $93.0 \%$ & $52.0 \%$ \\
$2008-09$ & 80 & 54 & 32 & 18 & $67.5 \%$ & $59.3 \%$ & $56.3 \%$ & $33.3 \%$ \\
$2009-10$ & 80 & 52 & 24 & 23 & $65.0 \%$ & $46.2 \%$ & $95.8 \%$ & $44.2 \%$ \\
$2010-11$ & 180 & $138(126)^{2}$ & 84 & - & $76.7 \%$ & $66.7 \%$ & - & - \\
\hline
\end{tabular}

${ }^{1}$ An additional 6 hatched chicks were added to the study: fledging and breeding success include these.

${ }^{2} \mathrm{~A}$ total of 138 burrows were found with eggs and 126 were monitored for hatching success. 
Table 4. Measured values of breeding success for species on Gough Island (in bold type) and values for the same species or congeneric species at sites with no, or low rates, of predation rates.

\begin{tabular}{lll}
\hline Species & Breeding success \% & Reference \\
\hline Puffinus gravis & $43 \%$ & This study \\
Puffinus huttoni & $47 \%$ & Cuthbert and Davis (2002) \\
Puffinus puffinus & $60 \%$ & Thomson and Furness (1991) \\
Puffinus tenuirostris & $48 \%$ & Serventy and Curry (1984) \\
Puffinus pacificus & $43 \%$ & Floyd and Swanson (1983) \\
Pterodroma mollis & $\mathbf{1 4 - 4 4} \%$ & This study \\
Pterodroma incerta & $\mathbf{2 0 - 2 3 \%}$ & Cuthbert (2004), Wanless et al. (2012) \\
Pterodroma macroptera & $60 \%$ & Cooper and Fourie (1991) \\
Pterodroma pycrofti & $59 \%$ & Pierce (2002) \\
Pterodroma hypoleuca & $82 \%$ & Seto and Conant (1996) \\
Pterodroma axillaris & $71-78 \%$ & Brooke (2004) \\
Pterodroma leucoptera & $50 \%{ }^{1}$ & DEC-NSW (2006) \\
Pachyptila vittata & $\mathbf{0 - 9} \%$ & This study \\
Pachyptila vittata & $60-72 \%{ }^{2}$ & van Rensburg and Bester (1988) \\
Pachyptila belcheri & $52 \%$ & Nevoux and Barbraud (2005) \\
Pachyptila belcheri & $63 \% 3$ & Catry et al. (2007) \\
Procellaria cinerea & $\mathbf{3 1 - 3 5 \%}$ & This study \\
Procellaria cinerea & $40-60 \%$ & Inchausti et al. (2003) \\
Procellaria cinerea & $75-80 \%$ & Schulz et al. (2005) \\
\hline
\end{tabular}

${ }^{1}$ Following predator control and habitat management.

${ }^{2}$ In predator free enclosures.

${ }^{3}$ In lowland areas with minimal predation rates.

were found with injuries consistent with mouse predation (Brown et al. 1998; Cuthbert and Hilton 2004). While breeding success of many seabirds can be highly variable, often in response to at-sea conditions (Warham 1990), we consider it very unlikely that environmental conditions would be responsible for consistently low breeding success and low burrow occupancy across four different species and over several years of monitoring. A further cause of low breeding success could be due to high rates of burrow competition, with larger species (such as Great Shearwaters) displacing smaller species on Gough, as has been observed for other seabirds (e.g. Ramos et al. 1997, Was et al. 2000). While such competition may occur on Gough the low levels of burrow occupancy seems likely to reduce the scale and impact of this upon breeding success. It is exceptional for house mice to be predators on the scale observed at Gough Island (Cuthbert and Hilton 2004, Wanless et al. 2007), and our study indicates that this source of mortality is impacting a wider range of species than previously considered.

Given the low values of breeding success observed in four species of petrels at Gough Island, are their populations likely to be stable or declining? Petrels are able to withstand several years of poor breeding success as they are long-lived, and even with consistently low breeding success, population declines are likely to be slow (e.g. Brooke et al. 2010). Population modelling undertaken for the Henderson Petrel Pterodroma atrata suggests that with values of annual adult survival set at $93 \%$, breeding success needs to average more than $25 \%$ in order for the population to be close to stable (Brooke et al. 2010). Values of breeding success for both Pterodroma species on Gough are close to this level, suggesting that despite poor breeding success populations could be close to stable provided adult survival is sufficiently high. Published information for Grey Petrels is limited, but values of breeding success from Kerguelen of $40-60 \%$ (Inchausti et al. 2003) and Macquarie Island 75-80\% (Schulz et al. 2005) indicate that in comparison breeding success for this species on Gough Island is low (Table 4). As well as suffering 
low breeding success on Gough Island, Grey Petrels are also often killed by commercial fishing operations (Barbraud et al. 2009) and in combination these two sources of mortality could be leading to population declines. Population modelling predicts a similar scenario for the Tristan Albatross, which like the Grey Petrel is impacted at sea and on land (Wanless et al. 2009). No demographic data are available for Broad-billed Prions, but with a breeding success of just $0-9 \%$ the species is almost certainly declining.

At least 12 species of burrowing petrel breed at Gough Island (Table 5) and our results demonstrate that breeding success was low in four out of five species studied. Angel and Cooper (2006) hypothesised that winter-breeding species and smaller species (diving petrels and storm petrels) are likely to be most impacted by mouse predation on Gough Island, and other studies have reported that invasive rats have a greater impact on smaller seabird species (Baker et al. 2002, Jones et al. 2008). These hypotheses are supported by our data which indicate a significant relationship between body size and breeding success as well as lower values of breeding success for the two winter breeding species (Figure I). If this relationship holds for all species of burrowing petrel on Gough Island then we predict that the impact of house mice on the remaining species is likely to be severe, as they are either winter breeders (Great-winged Petrel) or of small body size $(<350 \mathrm{~g}$; Table 5 and Figure 1$)$. Given these results we predict that widescale population declines are occurring among most burrowing petrels on Gough Island. The very low rates of burrow occupancy found for Broad-billed Prions (4-12\%) and Soft-plumaged Petrels (11-18\%) suggest that large-scale population declines may already have taken place for these two species, although some caution should be attached to these occupancy figures as it is difficult to separate burrows of the two species and large numbers of prions breed in caves on the island. If burrow occupancy values found in this study are applied to the population estimates in Cuthbert (2004) then populations of both Broad-billed Prions and Soft-plumaged Petrels could be far lower than previously estimated.

Earlier reports and observations of burrowing petrels at Gough Island lend some further credence to the fact that populations of many species have declined. The first detailed ornithological survey of Gough Island in 1955/56 (Swales 1965) described Little Shearwaters Puffinus assimilis as "extremely abundant", recorded that Kerguelen Petrels Lugensa brevirostris were so abundant that "so many thousands... were attracted to the lights... that it became necessary to turn them off

Table 5. Species of burrowing petrel on Gough Island indicating breeding season, breeding success, body mass and likely population trend based on the results of this study (underlined) and inferred population trend for other species (italics). Data for body mass are from Brooke (2004), Cuthbert (2004, 2005), Hockey et al. (2005) and authors' unpubl. data.

\begin{tabular}{lllll}
\hline Species & $\begin{array}{l}\text { Breeding } \\
\text { season }\end{array}$ & $\begin{array}{l}\text { Breeding } \\
\text { success (\%) }\end{array}$ & $\begin{array}{l}\text { Body } \\
\text { mass (g) }\end{array}$ & Trend \\
\hline Great Shearwater Puffinus gravis & Summer & $43 \%$ & $737-1130$ & Stable \\
Soft-plumaged Petrel Pterodroma mollis & Summer & $26 \%$ & $202-342$ & Decrease \\
Little Shearwater Puffinus assimilis & Summer & Unknown & $210-295$ & Decrease \\
Broad-billed Prion Pachyptila vittata & Summer & $6 \%$ & $155-235$ & Decrease \\
Grey Petrel Procellaria cinerea & Winter & $33 \%$ & $950-1220$ & $\underline{\text { Decrease }}$ \\
Great-winged Petrel Pterodroma macroptera & Winter & Unknown & $460-745$ & Decrease \\
Atlantic Petrel Pterodroma incerta & Winter & $20 \%$ & $420-720$ & Decrease \\
Kerguelen Petrel Pterodroma brevirostris & Summer & Unknown & $220-450$ & Decrease \\
Grey-backed Storm Petrel Garrodia nereis & Summer & Unknown & $26-40$ & Decrease \\
White-faced Storm Petrel Pelagodroma marina & Summer & Unknown & $45-60$ & Decrease \\
Fregatta storm petrels (F. grallarialtropica*) & Summer & Unknown & $45-65$ & Decrease \\
Common Diving Petrel Pelecanoides urinatrix & Summer & Unknown & $100-160$ & Decrease \\
\hline
\end{tabular}

*recent evidence suggests that both F. grallaria and F. tropica breed on Gough Island. 


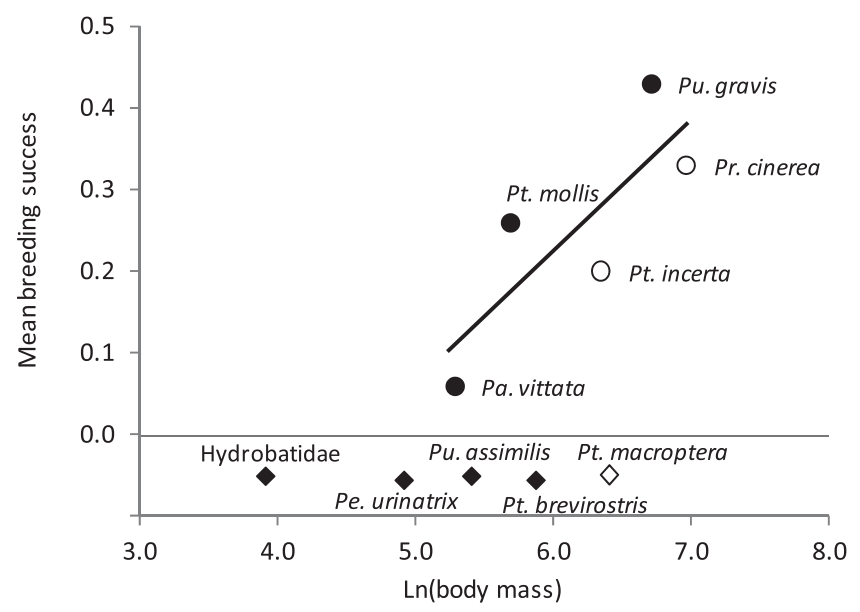

Figure 1. Relationship between ln body mass (g) and mean breeding success for monitored populations of burrowing petrels reported in this paper indicated by filled circles for summer breeding species and open circles for winter breeding species (the fitted correlation line for the 5 species is statistically significant: $\mathrm{R}^{2}=0.806, \mathrm{P}<0.05$ ) and ln body mass of unstudied species on Gough Island below with summer and winter breeding indicated by filled and unfilled diamond symbols. Species codes are: Atlantic petrel (Pt. incerta), soft-plumaged petrel (Pt. mollis), greatwinged petrel (Pt. macroptera), Kerguelen petrel (Pt. brevirostris), grey petrel (Pr. cinerea), great shearwater $(P u$. gravis), little shearwater ( $P u$. assimilis), broad-billed prion $(P a$. vitatta), common diving petrel (Pe. urinatrix) and storm petrels (Hydrobatidae).

again at once for the safety of the observers, the birds and the lights themselves", reported "large numbers" of Great-winged Petrels and described Common Diving Petrels as "abundant". Similarly, Ryan (2010) estimates on a single misty night in October 1984 that there were "tens of thousands of Broad-billed Prions, thousands of Soft-plumaged and Kerguelen Petrels, and hundreds of Atlantic Petrels, Little Shearwaters, Common Diving-petrels and White-faced and Grey-backed storm-petrels". By contrast numbers of birds seen spot-lighting at the same location over many nights in September-October 2009, recorded no Kerguelen Petrels, one Little Shearwater and two Grey-backed Storm Petrels. Ryan (2010) also reports that Little Shearwaters used to be commonly heard calling in tussock areas in the southeast of the island during the mid 1980s but are now no longer recorded. While there are obviously limitations to these conclusions based on a single night's observations from the mid-1980s, nonetheless it is striking that no similar observations of numbers on this scale have been recorded during the last decade, when year-round teams of fieldworkers have been present for five years since 2000/01. Despite specific searches, they have failed to locate any breeding burrows of Great-winged Petrels, Little Shearwaters, Common Diving Petrel or storm petrels, and have only found a few Kerguelen Petrel burrows. Some caution should be applied to comparing the surveys from 1955/56 with results from the last decade, as the earlier surveys were undertaken on the east coast at The Glen, whereas most recent fieldwork has been undertaken in upland areas of the island and at Transvaal Bay. Nonetheless, despite some evidence from birds attracted to the lights of fishing boats anchored offshore from The Glen that this site may hold greater numbers of Little Shearwaters and Kerguelen Petrels than other areas (PGR and ES pers obs.) it is clear from overnight visits to the site that there are considerably fewer birds present than described by Swales (1965). While these comparisons from The Glen are qualitative, the observations of Ryan (2010) from 1984 and 2009 were undertaken at the same site and provide stronger evidence for large-scale declines. 
House mice have been present on Gough Island since the early $19^{\text {th }}$ century (Rowe-Rowe and Crafford 1992) and given that numbers of burrowing petrels appeared to remain abundant on Gough Island until at least the 196os, the question arises as to why large scale impacts of mice and apparent reductions in petrel numbers have only been observed in the last few decades? The negative impacts of rats on seabird populations are usually acute and relatively rapid (Atkinson 1985), although in some circumstances gradual population declines can take place over hundreds of years (Brooke et al. 2010). Comparable knowledge on the impacts of House mice on seabirds is lacking, because large-scale predatory behaviour by the species appears to be the exception rather than the rule. Given the impacts that mice are now having on Gough Island and the presence of very large numbers of birds until the mid $20^{\text {th }}$ century we consider it likely that, for currently unknown reasons, the predatory behaviour of mice has increased in recent decades to the point whereby the impact of predation is now observed across most species on the island.

In conclusion, this study indicates that the predicted impacts of house mice on winter-breeding petrels (Angel and Cooper 2006) are indeed severe, and moreover that several summer-breeding petrels appear to be impacted, especially the smaller species. If the levels of breeding success observed in this study are typical, populations of most burrowing petrels on Gough Island are likely to be declining. Very low levels of burrow occupancy by two formerly abundant species and comparison of numbers to earlier records strongly suggest that large-scale declines may have already taken place for many species and that Gough Island's burrowing petrel community could be at the start of a catastrophic collapse. The only feasible and practical solution to this situation is the eradication of house mice from the island. This conservation action previously has been recommended to protect the "Critically Endangered" Tristan Albatross and Gough Bunting, and the "Endangered" Atlantic Petrel (Cuthbert and Hilton 2004, Wanless et al. 2009). Our study indicates that a far larger range of species would benefit from removing mice from the island. The eradication of invasive rodents has become one of the most important conservation actions available for protecting native species on islands (Howald et al. 2007) and while eradicating house mice from Gough Island would be challenging and expensive, a review has indicated that it should be feasible (Parkes 2008) and planning for this operation is underway (Torr et al. 2011). If an eradication operation is successful, populations of burrowing petrels should recover relatively rapidly as large numbers of adult breeding birds remain and improved breeding success should occur immediately after the removal of mice. A successful eradication would remove the key conservation threat to more than ten seabird species and restore Gough Island's status as one of the world's most important seabird breeding islands.

\section{Acknowledgements}

Permission to undertake this work was granted by the Tristan da Cunha Conservation Department and funding was provided by the UK Government's Overseas Territories Environment Programme (OTEP). We are grateful for logistical support from the Royal Society for the Protection of Birds, the South African National Antarctic Programme (Department of Environmental Affairs), and the University of Cape Town.

\section{References}

Angel, A. and Cooper, J. (2006) A review of the impacts of introduced rodents on the islands of Tristan da Cunha and Gough. Sandy, UK: RSPB. (RSPB Research Report No. 17).

Angel, A., Wanless, R. M. and Cooper, J. (2009) Review of impacts of the introduced house mouse on islands in the Southern Ocean: are mice equivalent to rats? Biol. Invasions 11: 1743-1754.

Atkinson, I. A. E. (1985) The spread of commensal species of Rattus to oceanic islands and their effect on island avifaunas. Pages $35-81$ in P. J. Moors, ed. Conservation 
of island birds. Cambridge, UK: International Council for Bird Preservation.

Barbraud, C., Delord, K., Marteau, C. and Weimerskirch, H. (2009) Estimates of population size of White-chinned Petrels and Grey Petrels at Kerguelen Islands and sensitivity to fisheries. Anim. Conserv. 12: 258265.

BirdLife International (2004) Threatened birds of the world 2004 (CD-ROM). Cambridge, UK: BirdLife International.

Brooke, M. (2004) Albatrosses and petrels across the world. Oxford, UK: Oxford University Press.

Brooke, M. de L., O'Connell, T. C., Wingate, D., Madeiros, J., Hilton, G. M. and Ratcliffe, N. (2010) Potential for rat predation to cause decline of the globally threatened Henderson Petrel Pterodroma atrata: evidence from the field, stable isotopes and population modelling. Endangered Species Res. 11: 47-59.

Brown, K. P., Moller, H., Innes, J. and Jansen, P. (1998) Identifying predators at nests of small birds in a New Zealand forest. Ibis 140: 274-279.

Butchart, S. H. M. (2008) Red List indices to measure the sustainability of species use and impacts of invasive alien species. Bird Conserv. Internatn. 18: S245-S262.

Catry, P., Silva, M. C., MacKay, S., Campos, A., Masello, J., Quillfeldt, P. and Strange, I. J. (2007) Can Thin-billed Prions Pachyptila belcheri breed successfully on an island with introduced rats, mice and cats? The case of New Island, Falkland Islands. Polar Biol. 30: 391-394.

Collar, N. J. and Stuart, N. S. (1985) Threatened birds of Africa and related islands. The ICBP/ IUCN Red Data Book, Part 1. Third edition. Cambridge, UK and Gland, Switzerland: International Council for Bird Preservation and International Union for Conservation of Nature and Natural Resources.

Cooper, J. and Fourie, A. (1991) Improved breeding success of Great-winged Petrels Pterodroma macroptera following control of feral cats Felis catus at subantarctic Marion Island. Bird Conserv. Internatn. 1: $171-175$.

Cooper, J. and Ryan, P. G. (1994) Management plan for the Gough Island wildlife reserve. Edinburgh, Tristan da Cunha, South Atlantic: Government of Tristan da Cunha.

Croxall, J. P., Butchart, S. H. M., Lascelles, B., Stattersfield, A. J., Sullivan, B., Symes, A. and Taylor, P. (2012) Seabird conservation status, threats and priority actions: a global assessment. Bird Conserv. Internatn. 22: 1-34. doi:10.1017/S0959270912000020.

Cuthbert, R. (2004) Breeding biology and population estimate of the Atlantic Petrel, Pterodroma incerta, and other burrowing petrels at Gough Island, South Atlantic Ocean. Emu 104: 221-228.

Cuthbert, R. J. (2005) Breeding biology, chick growth and provisioning of Great Shearwaters (Puffinus gravis) at Gough Island, South Atlantic Ocean. Emu 105: 305-310.

Cuthbert, R. J. and Davis, L. S. (2002) Adult survival and productivity of Hutton's Shearwaters. Ibis 144: 423-432.

Cuthbert, R. and Hilton, G. (2004) Introduced House mice Mus musculus: a significant predator of endangered and endemic birds on Gough Island, South Atlantic Ocean? Biol. Conserv. 117: 483-489.

Cuthbert, R. and Sommer, E. (2004a) Population size and trends of four globally threatened seabirds at Gough Island, South Atlantic Ocean. Marine Ornithol. 32: 97-103.

Cuthbert, R. J. and Sommer, E. S. (2004b). Gough Island bird monitoring manual. Sandy, UK: Royal Society for the Protection of Birds. (RSPB Research Report No 5).

Cuthbert, R. J., Visser, P., Louw, H., Rexer-Huber, K., Parker, G. and Ryan, P. G. (2011) Preparations for the eradication of mice from Gough Island: results of bait acceptance trials above ground and around cave systems. Pp. 47-50 in C. R. Veitch, M. N. Clout and D. R. Towns, eds. (2011) Island invasives: Eradication and management. Gland, Switzerland: IUCN.

Cuthbert, R. J., Cooper, J. and Ryan, P. G. (submitted) Population trends and breeding success of albatrosses and giant petrels at Gough Island. Antarctic Sci.

DEC-NSW (2006) Gould's Petrel (Pterodroma leucoptera leucoptera) recovery plan. Hurstville, NSW: Department of Environment and Conservation (NSW). 
Floyd, R. B. and Swanson, N. M. (1983) Wedge-tailed Shearwaters on Muttonbird Island: an estimate of the breeding success and breeding population. Еmu 82: 244-250.

Hilton, G. M. and Cuthbert, R. J. (2010) The catastrophic impact of invasive mammalian predators on birds of the UK Overseas Territories: A review and synthesis. Ibis 152: $443-458$.

Hockey, P. A. R., Dean, W. R. J. and Ryan, P. G. (2005) Roberts' birds of southern Africa (7th ed.). Cape Town, South Africa: The Trustees of the John Voelcker Bird Book Fund. Howald, G., Donlan, C. J., Galván, J. P., Russell, J., Parkes, J., Samaniego, A., Wang, Y., Veitch, D., Genovesi, P., Pascal, M., Saunders, A. and Tershy, B. (2007) Invasive rodent eradication on islands. Conserv. Biol. 21: 1258-1268.

Inchausti, P., Guinet, C., Koudil, M., Durbec, J. P., Barbraud, C., Weimerskirch, H., Cherel, Y. and Jouventin, P. (2003) Inter-annual variability in the breeding performance of seabirds in relation to oceanographic anomalies that affect the Crozet and the Kerguelen sectors of the Southern Ocean. J. Avian Biol. 34: 170-176.

Jones, H. P., Tershy, B. R., Zavaleta, E. A., Croll, D. A., Keitt, B. S., Finkelstein, M. E. and Howald, G. R. (2008) Severity of the effects of invasive rats on seabirds: A global review. Conserv. Biol. 22:16-26.

Moors, P. J. and Atkinson, I. A. E. (1984) Predation on seabirds by introduced animals, and factors affecting its severity. Pp. 667-690 in P. J. Moors, ed. Conservation of island birds: case studies for the management of threatened island birds. Cambridge, UK: International Council for Bird Preservation.

Nevoux, M. and Barbraud, C. (2005) Relationships between sea ice concentration, sea surface temperature and demographic traits of thin-billed prions. Polar Biol. 29: 445-453.

Parkes, J. (2008) A feasibility study for the eradication of house mice from Gough Island. Sandy, UK: Royal Society for the Protection of Birds. (RSPB Research Report No. 34).

Pierce, R. J. (2002) Kiore (Rattus exulans) impact on breeding success of Pycroft's Petrels and Little Shearwaters. Wellington, NZ: Department of Conservation.
Ramos, J. A., Monteiro, L. R., Sola, E. and Moniz, Z. (1997) Characteristics and competition for nest cavities in burrowing Procellariiformes. The Condor 99: 634641.

Rowe-Rowe, D. T. and Crafford, J. E. (1992) Density, body size and reproduction of feral mice on Gough Island. South Afr. J. Zool. 27: 1-5.

Ryan, P. G., ed. (2007) Field guide to the animals and plants of Tristan da Cunha and Gough Island. Newbury, UK: Pisces Publications.

Ryan, P. (2010) Tipping point: mice eroding Gough's seabirds. Africa Birds \& Birding 15: 13 .

Ryan, P. G. and Cuthbert, R. J. (2008) The biology and conservation status of Gough Bunting Rowettia goughensis. Bull. Brit. Ornithol. Club 128: 242-253.

Ryan, P. G., Cooper, J. and Glass, J. P. (2001) Population status, breeding biology and conservation of the Tristan albatross. Bird Conserv. Internatn. 11: 35-48.

Serventy, D. L. and Curry, P. J. (1984) Observations on colony size, breeding success, recruitment and inter-colony dispersal in a Tasmanian colony of Short-tailed Shearwaters Puffinus tenuirostris over a 30-year period. Emu 84: 71-79.

Seto, N. W. H. and Conant, S. (1996) The effects of rat (Rattus rattus) predation on the reproductive success of the Bonin Petrel (Pterodroma hypoleuca) on Midway Atoll. Colonial Waterbirds 19: 171-185.

Schulz, M., Robinson, S. and Gales, R. (2005) Breeding of the grey petrel (Procelleria cinerea) on Macquarie Island: population size and nesting habitat. Emu 105: 323-329. Swales, M. K. (1965) The seabirds of Gough Island. Ibis 107: 17-42: 215-229.

Thompson, K. R. and Furness, R. W. (1991) The influence of rainfall and nest-site quality on the population dynamics of the Manx Shearwater Puffinus puffinus on Rhum. J. Zool., Lond. 225: 427-437.

Torr, N., Golding, C. and Cuthbert, R. J. (2011) Preliminary operational plan for eradicating house mice from Gough Island. Sandy, UK: Royal Society for the Protection of Birds.

Van Rensburg, P. J. J. and Bester, M. N. (1988) The effect of cat Felis catus predation on three 
breeding Procellariidae species on Marion Island. South Afr. J. Zool. 23: 301-305.

Wace, N. M. (1961) The vegetation of Gough Island. Ecol. Monogr. 31: 337-367.

Wanless, R. M., Angel, A., Cuthbert, R. J., Hilton, G. M. and Ryan, P. G. (2007) Can predation by invasive mice drive seabird extinctions? Biol. Lett. 3: 241-244.

Wanless, R. M., Ryan, P. G., Altwegg, R., Angel, A., Cooper, J. Cuthbert, R. and Hilton, G. M. (2009) From both sides: dire demographic consequences of carnivorous mice and longlining for the Critically Endangered Tristan Albatrosses on Gough Island. Biol. Conserv. 142: 1710-1718.
Wanless, R. M., Ratcliffe, A., Angel, A., Bowie, B. C., Cita, K., Hilton, G. M., Kritzinger, P., Ryan, P. G. and Slabber, M. (2012) Predation of Atlantic Petrel chicks by house mice on Gough Island. Anim. Conserv. doi:10.1111/j.1469-1795.2012.00534.x

Warham, J. (1990) The petrels: their ecology and breeding systems. London, UK: Academic Press.

Was, N. W., Sullivan, W. J. and Wilson, K-J. (2000) Burrow completion between Broadbilled prions (Pachyptila vittata) and the endangered Chatham Petrel (Pterodroma axillaris). Wellington, NZ: Department of Conservation.

RICHARD J. CUTHBERT*, HENK LOUW, JEROEN LURLING, GRAHAM PARKER, KALINKA REXER-HUBER, PAUL VISSER

Royal Society for the Protection of Birds, The Lodge, Sandy, Bedfordshire SG19 2DL, UK.

ERICA SOMMER

84 Nottingham Road, Belper, Derbyshire, DE56 1JH, UK.

PETER G. RYAN

DST-NRF Centre of Excellence for Invasion Biology, Faculty of Science, Stellenbosch University, Private Bag X1, Matieland 7602, South Africa.

*Author for correspondence; e-mail: richard_cuthbert@yahoo.co.uk

Received 26 April 2012; revision accepted 17 September 2012;

Published online 22 March 2013 